\title{
AC 2012-3108: EFFECTIVE LOW-BUDGET APPROACH TO TEACHING PHOTOVOLTAIC SYSTEMS TO ELECTRICAL ENGINEERING TECH- NOLOGY STUDENTS AT COMMUNITY COLLEGES
}

\section{Dr. Elena V. Brewer, Erie Community College}

Elena V. Brewer is an instructor of Electrical Engineering Technology at Erie Community College. She received her Ph.D. in physics from the State University of New York, Buffalo. Her teaching interests include photovoltaic systems, DC/AC circuit analysis, digital electronics, PLCs, electrical motors and controls, and college and technical physics.

\section{Anthony P. Dalessio, Erie Community College}

Anthony P. Dalessio is an Assistant Professor of electrical engineering technology at Erie Community College. He earned a B.S. and M.S. in electrical engineering from the State University of New York at Buffalo. His teaching interests include analog and digital electronics, wireless communications, and renewable energy. 


\title{
Effective Low-Budget Approach to Teaching Photovoltaic Systems to Electrical Engineering Technology Students at Community Colleges
}

\begin{abstract}
This paper presents a unique approach to introduction of the photovoltaic course and corresponding laboratory into the Electrical Engineering Technology program at the two-year college level implemented at Erie Community College in Buffalo, NY. This approach uses the middle ground between the extremely technical courses for photovoltaic systems at four-year colleges and universities and the more simplified approach to photovoltaic systems at the trade level targeting PV installers. It balances the necessity of rigorous theoretical overview of PV components and their behavior under different weather and load conditions, with requirements of significant hands-on course/lab component, and with strict budgetary constraints common to two-year schools. The course methodology, its presentation, and laboratory design are briefly outlined in this paper.
\end{abstract}

\section{Introduction}

In the last several years, substantial interest was generated towards introducing photovoltaic courses into various college/university programs due to rapid development of photovoltaic industry. However, most courses and programs being developed at the university or college level target either engineering students ${ }^{1}$ or PV installers ${ }^{2}$. In addition, various private educational companies emerged that conduct training in photovoltaic (PV) systems and PV installations, with Solar Energy International being one such example ${ }^{3}$. A more comprehensive approach to renewable technologies training in general, and photovoltaic technologies in particular, is used by the Consortium for Education in Renewable Energy Technologies ${ }^{4}$. However, in both cases, the courses or training workshops offered on photovoltaic topics are geared more towards training the PV installers. After looking into many installer-targeted courses, we developed a perception that such courses do not provide theoretical background on photovoltaic components' operation (such as solar panels, inverters, charge controllers, power conditioning units or PCUs) at the level sufficient for the electrical engineering technology (EET) program. On the opposite side of the spectrum, the courses targeting engineering students in four-year schools cover the component analysis, including material science topics, at the level far above the level of theoretical preparation of EET students without covering enough of the system integration and development topics. Our goal was to build a course that would help students to develop comprehensive understanding of all aspects of performing PV systems design including but not limited to understanding of component behavior in such systems under various weather and load conditions.

In our opinion, the effective introduction of photovoltaic systems to EET students enrolled in two-year programs at community college requires a different approach that would have to meet the challenge of balancing the following required competencies: sufficient theoretical background in PV modules operation and battery operation; overview of electronics in charge controllers, inverters and other components, necessary for understanding their behavior under various weather and load conditions; understanding and ability to perform load analysis, site 
survey, and shading analysis; ability to perform sizing analysis of modules, inverters, charge controllers and Balance-of-System (BOS) components to complete the PV system design in accordance with National Electrical Code (NEC) requirements; familiarization with wind load and other structural analysis techniques; and an ability to conduct economic analysis of the PV system. Other criteria that need to be balanced in PV course and corresponding laboratory are: incorporation of hands-on approach in lecture and lab; budgetary constraints for the development of the lab component of the course; exposure of students to a sufficient assortment of PV technologies; portability of PV equipment; and ability to run the laboratory experiments indoors when a controlled solar source is required as well as when weather conditions are not conducive to the PV experiment. The PV Systems course and corresponding laboratory developed at our institution incorporate all above mentioned requirements.

\section{Photovoltaic (PV) systems lecture component}

The first challenge we met was the choice of the course textbook(s). We evaluated all textbooks on photovoltaic systems and solar power available on the market at that time. Most of the available textbooks had the same flaws as the general course offerings for photovoltaic systems: they were either at the trade level geared towards installer training, or at the four-year school engineering level. The "Electricity from Sunlight - An Introduction to Photovoltaics" by Paul Lynn $^{5}$ presented material in too simplistic manner which would be suitable for the trade level course or the survey course textbook, but not detailed enough to make it a good resource for the EET course. The textbook used by Solar Energy International ${ }^{6}$ was an excellent book for the PV installer course or a lower level introductory PV course, but it was lacking serious discussion of electrical and electronics components necessary for more in-depth understanding of PV components and their behavior in the PV system expected in the EET program. Our evaluation of "Photovoltaic Systems" by Dunlop ${ }^{7}$ rendered it generally acceptable for our purposes with material being presented at the level consistent with the theoretical and technical preparation level of our students during their $4^{\text {th }}$ semester of studies. By the $4^{\text {th }}$ semester, our students already acquire substantial background in DC/AC electricity, electronics, and physics, to be able to use this comprehensive course resource effectively, even though the book was marketed as targeting more advanced courses in four-year schools. Therefore, we adopted "Photovoltaic Systems” by Dunlop as a required text for our Photovoltaic Systems lecture course. However, it still was lacking enough resources for performing serious PV system design work. So, we decided to supplement it by the "Photovoltaic Systems Design” text by R. Messenger ${ }^{8}$ that has some step-by-step discussion of system design issues with examples of designing grid-tied, stand-alone, and hybrid systems. This textbook is specified as recommended for the design component of our course. Since it is not required, it is made available to the students either through the college bookstore for purchase or rental, or through the campus library circulation system.

Furthermore, in addition to the regular lecture/demonstration mixture, the successful methodology for the lecture component of the course includes variety of hands-on homework assignments such as: load analysis using Kill-A-Watt meters; shading analysis of the actual location and production of industry-standard shading report with Solar Pathfinder; analysis of available irradiance using published tables and online resources such as PV Watts calculator; work with GIS maps depicting landscape slopes or temperature levels; sizing of inverters, wires, 
disconnects, over-current protection devices (OCPDs) and other components of PV System according to NEC guidelines; and performing economic analysis of the PV system.

Student progress is assessed based on the mixture of homework assignments, tests and final group design project. The final project involves application of all learned steps and techniques to design a viable PV System in a teamwork environment, production of project report, and preparation of a 15-20 minute PowerPoint presentation. Table 1 presents required modules that students must cover in their design project and acceptable modes of implementation for each module.

Table 1. Design Project Modules

\begin{tabular}{|c|c|c|}
\hline Module & Mode of Implementation & Deliverable \\
\hline $\begin{array}{l}\text { Electrical load } \\
\text { analysis }\end{array}$ & $\begin{array}{l}\text { Kill-A-Watt meter measurements, } \\
\text { estimates based on the electric bill, or } \\
\text { manufacturer's power ratings }\end{array}$ & $\begin{array}{l}\text { table with load analysis } \\
\text { calculations }\end{array}$ \\
\hline $\begin{array}{l}\text { Critical Design } \\
\text { Month analysis } \\
\text { (for stand-alone } \\
\text { or hybrid } \\
\text { systems) }\end{array}$ & $\begin{array}{l}\text { comparison of loads to available insolation } \\
\text { for every month to determine the month } \\
\text { with the largest ratio of required energy to } \\
\text { the peak-sun-hours available }\end{array}$ & $\begin{array}{l}\text { the load in KWh/day and solar } \\
\text { irradiance in peak-sun-hours } \\
\text { for the worst-case scenario } \\
\text { month }\end{array}$ \\
\hline Shading analysis & Solar Pathfinder measurements & $\begin{array}{l}\text { industry-standard report using } \\
\text { Solar Pathfinder software }\end{array}$ \\
\hline $\begin{array}{l}\text { Sizing of major } \\
\text { system } \\
\text { components }\end{array}$ & $\begin{array}{l}\text { detailed sizing calculations, including } \\
\text { appropriate de-rates due to temperature, } \\
\text { irradiance level, shading, and efficiency }\end{array}$ & $\begin{array}{l}\text { schematic of the PV system } \\
\text { with specifications for each } \\
\text { system component, and } \\
\text { manufacturer's specifications } \\
\text { for every component }\end{array}$ \\
\hline $\begin{array}{l}\text { Sizing of Balance } \\
\text { Of System } \\
\text { components }\end{array}$ & $\begin{array}{l}\text { detailed calculations, including appropriate } \\
\text { temperature and conduit-de-rates and } \\
\text { voltage drops for the wire sizing, OCPD } \\
\text { sizing, DC/AC disconnects sizing, etc. }\end{array}$ & $\begin{array}{l}\text { appropriate wire gauges for } \\
\text { each segment of PV system, } \\
\text { and manufacturer's } \\
\text { specifications for OCPDs and } \\
\text { disconnects. }\end{array}$ \\
\hline $\begin{array}{l}\text { Mounting } \\
\text { solutions }\end{array}$ & $\begin{array}{l}\text { ground-mounted, pole-mounted, or roof- } \\
\text { mounted equipment specified }\end{array}$ & $\begin{array}{l}\text { manufacturer's specifications } \\
\text { for the mounting system }\end{array}$ \\
\hline $\begin{array}{l}\text { Economic } \\
\text { analysis }\end{array}$ & $\begin{array}{l}\text { economic analysis including: pricing of all } \\
\text { the components and labor; identifying } \\
\text { applicable federal or state incentives, } \\
\text { renewable energy credits, feed-in-tariff, } \\
\text { etc.; identifying future savings }\end{array}$ & $\begin{array}{l}\text { the spreadsheet summarizing } \\
\text { system costs, incentives, and } \\
\text { return-on-investment period }\end{array}$ \\
\hline
\end{tabular}

At the completion of the project, students present complete design for a real photovoltaic system accompanied by equipment specs, price quotes and economic feasibility analysis. PV systems 
components that students specify must comply with the National Electric Code (NEC) article 690 "Solar Photovoltaic Systems" as well as with related articles 110, 210, 240, 250, 310 and 480. Students must perform and present results of sizing calculations for solar panels, inverters, charge controllers, battery banks, and of course wires that are done according to NEC standards. As an example of wire sizing, students must start with nominal current-carrying capacity of the particular copper wire gauge and adjust it for temperature and conduit de-rates and maximum voltage drop requirements on a DC or AC wire to determine actual ampacity of the wire. Then, they must make sure that either total PV current or continuous current, whichever is applicable, does not exceed de-rated ampacity of the wire. Furthermore, students must present their results in the form of the PowerPoint presentation in front of their peers. The grading is conducted based on the rubrics evaluating the use of visuals, overall structure, technical content, general content, appropriateness, source references, oral communications, technical grammar, elocution, contact with audience, handling questions, and length of presentation. The design project proved to be an effective way to help students to organize all the information they learned in the course. The quality of the majority of the projects during the two semesters we ran the course was impressive. Students were interested in seeing the successful completion of the project and did a thorough job on working out all the necessary details and putting them together.

\section{Photovoltaic (PV) systems laboratory component}

The laboratory component of the course was designed using an innovative approach. The lab experiments are designed using an assortment of small inexpensive portable 5-6W solar modules (monocrystalline silicon, polycrystalline silicon, amorphous silicon, and copper indium selenium), inverters ( $12 \mathrm{~V}$ and $24 \mathrm{~V}$ pure sine, pulse width modulated, modified square wave), charge controllers (12V and 24V), loads (AC/DC lights, AC/DC water pumps, radios), AGM batteries, solar irradiance sensors, and temperature sensors. Furthermore, the MetalHalide/High-Pressure Sodium (MH/HPS) light sources, as shown in Figure 1, are used as controlled light sources for indoor experiments that must use controlled level of irradiance or as back-up light sources for conducting experiments indoors due to poor weather conditions, especially during winter months.
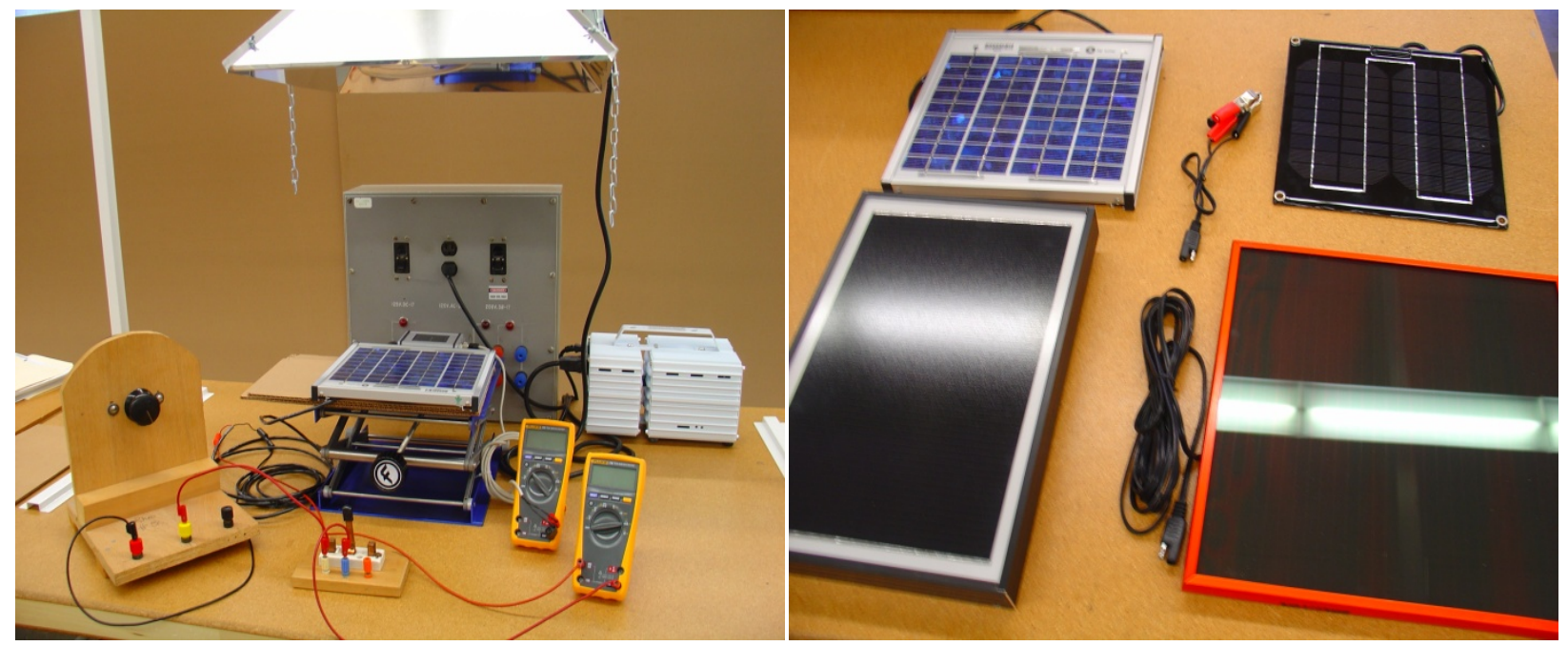

Figure 1. Setup for indoor labs (left) and assortment of PV panels used in the lab (right) 
We opted out of using specially designed PV trainers. Instead students have access to various technologies in PV panels, inverters, charge controllers, and others. They have ample hands-on experience wiring up small PV systems and taking performance data. We generally allow two students per laboratory group, so that everybody gets a chance to work with the equipment. Originally, the emphasis was made on launching the lab course with equipment representative of the industry practices under low budget. Later on, as financial situation permitted, we added some additional equipment. The list of original equipment used in the laboratory design is given in Table 2. The overall cost of equipping 8 laboratory work stations was $\$ 22,340$ that was funded from Carl D. Perkins Career and Technical Education Act funding.

Table 2. List of the PV Laboratory Equipment

\begin{tabular}{|l|l|l|l|}
\hline Equipment & Source & Quantity & $\begin{array}{l}\text { Price per } \\
\text { each (US\$) }\end{array}$ \\
\hline 6W monocrystalline Si panel & SunWize & 8 & 74.50 \\
\hline 5W polycrystalline Si panel & BP Solar & 8 & 69.50 \\
\hline 5W amorphous Si panel & Brunton & 8 & 65.43 \\
\hline 5W copper indium selenium panel & AEE Solar & 8 & 27.00 \\
\hline 1000W MH/HPS bulb & Eye Hortilux & 8 & 155.00 \\
\hline MH 1000W Ballast & Harvest Pro Elite & 8 & 140.00 \\
\hline Reflector for MH/HPS bulb & Agrotech & 8 & 53.00 \\
\hline Reflector stand & SunStand & 8 & 80.00 \\
\hline 12V pure sine wave inverter & Exeltech & 8 & 211.25 \\
\hline $\begin{array}{l}\text { Pro-Watt 300 12V modified square } \\
\text { wave inverter }\end{array}$ & Wagan & 8 & 30.43 \\
\hline 12V pulse-width modulated inverter & TrippLite & 8 & 27.99 \\
\hline 24V modified square wave inverter & Power Bright & 8 & 34.99 \\
\hline $\begin{array}{l}\text { 10A 12V SS-10L charge controller with } \\
\text { low voltage disconnect }\end{array}$ & Morningstar & 8 & 58.50 \\
\hline 10A 24V series charge controller & Morningtar & 8 & 60.00 \\
\hline Solar irradiance meter & IMT Solar & 8 & 353.00 \\
\hline $\begin{array}{l}\text { Fluke digital multimeter with } \\
\text { temperature sensors }\end{array}$ & Fluke & 8 & 222.57 \\
\hline 13.8V 23A power supplies & Samplex & 8 & 154.99 \\
\hline Lab jacks & Fisher Scientific Co. & 8 & 126.75 \\
\hline Kill-A-Watt meter & P3 International & 8 & 27.88 \\
\hline 5W DC water pump & Sunterra & 8 & 9.99 \\
\hline 2.5W AC pump & Annex Depot Inc. & 8 & 15.50 \\
\hline Solar Pathfinder & IMT Solar & 8 & 275.00 \\
\hline $\begin{array}{l}\text { Solar Pathfinder software (2 key codes } \\
\text { each) }\end{array}$ & IMT Solar & 4 & 140.00 \\
\hline 12V 7Ah SLA batteries & Prism & 16 & 15.87 \\
\hline Long pass filters & Schott N. America Inc & 14 & 238.57 \\
\hline & & &
\end{tabular}


The MH/HPS lamps work fairly well as a replacement source of light for indoor experiments, but there are some limitations. They were chosen because the spectrum of light generated by such sources is very close to the natural solar spectrum. However, the MH/HPS spectrum is made of discrete spectrum lines, whereas the solar spectrum is more continuous. Therefore, the performance of solar panels is affected by the differences in spectrum. The other factor that affects the solar panels' performance is the temperature. The MH/HPS lamps produce excessive heat at close distances from the panels which decreases the performance of the panels. Also, the light distribution over the panel is not uniform at close distances from the light source. As a result, the performance of the PV panels is lower under the MH/HPS light source compared to the natural solar light with efficiency being reduced by about $50 \%$. The list of experiments developed as part of the PV laboratory is given in Table 3.

Table 3. List of PV Laboratory Experiments

\begin{tabular}{|c|c|c|c|}
\hline & Experiment & Description & $\begin{array}{l}\text { Inside/ } \\
\text { Outside }\end{array}$ \\
\hline 1 & Photovoltaic effect & $\begin{array}{l}\text { The dependence of photovoltaic effect on the wavelength } \\
\text { of incoming light and irradiance level is tested. }\end{array}$ & $\begin{array}{l}\text { inside } \\
\text { only }\end{array}$ \\
\hline 2 & $\begin{array}{l}\text { Performance of } \\
\text { various PV panels }\end{array}$ & $\begin{array}{l}\text { Students determine and compare maximum power point, } \\
\text { fill factor and efficiency of various PV panels. }\end{array}$ & $\begin{array}{l}\text { inside or } \\
\text { outside }\end{array}$ \\
\hline 3 & $\begin{array}{l}\text { Temperature } \\
\text { effects on PV } \\
\text { panels }\end{array}$ & $\begin{array}{l}\text { Students learn how temperature of the panel affects voltage } \\
\text { and power produced by the panel as well as the shape of } \\
\text { the I-V curve. }\end{array}$ & $\begin{array}{l}\text { inside or } \\
\text { outside }\end{array}$ \\
\hline 4 & $\begin{array}{l}\text { PV modules in } \\
\text { series, parallel and } \\
\text { series/parallel } \\
\text { combinations }\end{array}$ & $\begin{array}{l}\text { Students predict, measure and compare the voltage, current } \\
\text { and power produced by matching and mismatching PV } \\
\text { panels connected in series, parallel or series parallel } \\
\text { combinations. I-V curve are also obtained and compared. }\end{array}$ & $\begin{array}{l}\text { inside or } \\
\text { outside }\end{array}$ \\
\hline 5 & $\begin{array}{l}\text { Irradiance } \\
\text { response }\end{array}$ & $\begin{array}{l}\text { Students test the effects of the panel's tilt and azimuth } \\
\text { angles on the solar panel's performance. }\end{array}$ & $\begin{array}{l}\text { outside } \\
\text { only }\end{array}$ \\
\hline 6 & Shading analysis & $\begin{array}{l}\text { Students test the effects of shading of portions of the PV } \\
\text { panel on its outputs. They also perform shading analysis } \\
\text { and produce the industry-standard shading report using } \\
\text { Solar Pathfinder equipment/software. }\end{array}$ & $\begin{array}{l}\text { inside or } \\
\text { outside }\end{array}$ \\
\hline 7 & $\begin{array}{l}\text { Charging and } \\
\text { discharging } \\
\text { batteries in PV } \\
\text { systems with } \\
\text { charge controllers }\end{array}$ & $\begin{array}{l}\text { Students take measurements to reconstruct the charging } \\
\text { curve (for voltages and currents) and to identify different } \\
\text { battery-charging stages. They also experimentally } \\
\text { determine low voltage disconnect and reconnect points of } \\
\text { the charge controller. }\end{array}$ & $\begin{array}{l}\text { inside } \\
\text { only }\end{array}$ \\
\hline 8 & Inverters & $\begin{array}{l}\text { Students measure waveforms and frequency spectrum for } \\
\text { various inverter technologies (pure sine, modified square } \\
\text { wave, PWM), the effect of the load on the wave's duty } \\
\text { cycle (using the oscilloscope) and on the efficiency. }\end{array}$ & inside \\
\hline 9 & $\begin{array}{l}\text { Battery-less stand- } \\
\text { alone systems }\end{array}$ & $\begin{array}{l}\text { Students size, wire and measure the performance of the } \\
\text { battery-less PV systems to power DC and AC water } \\
\text { pumps. }\end{array}$ & $\begin{array}{l}\text { inside or } \\
\text { outside }\end{array}$ \\
\hline
\end{tabular}


Most of the experiments can be performed either inside or outside. For example, Figure 2 shows circuit diagrams used with the inside and outside setups for laboratory experiments 2 and 6 in the Table 3. The I-V Curve Analyzer is utilized with the outside setup, whereas manual measurements of currents and voltages across various resistance values of the rheostat are necessary to build an I-V Curve manually from exposure of the PV panel(s) to the MH/HPS source. However, some experiments can be conducted inside only due to equipment specifications. Other experiments have to be done in a natural sunlight making them outside specific. In either case, we have enough flexibility to rearrange the order in which experiments are conducted to accommodate any weather conditions.
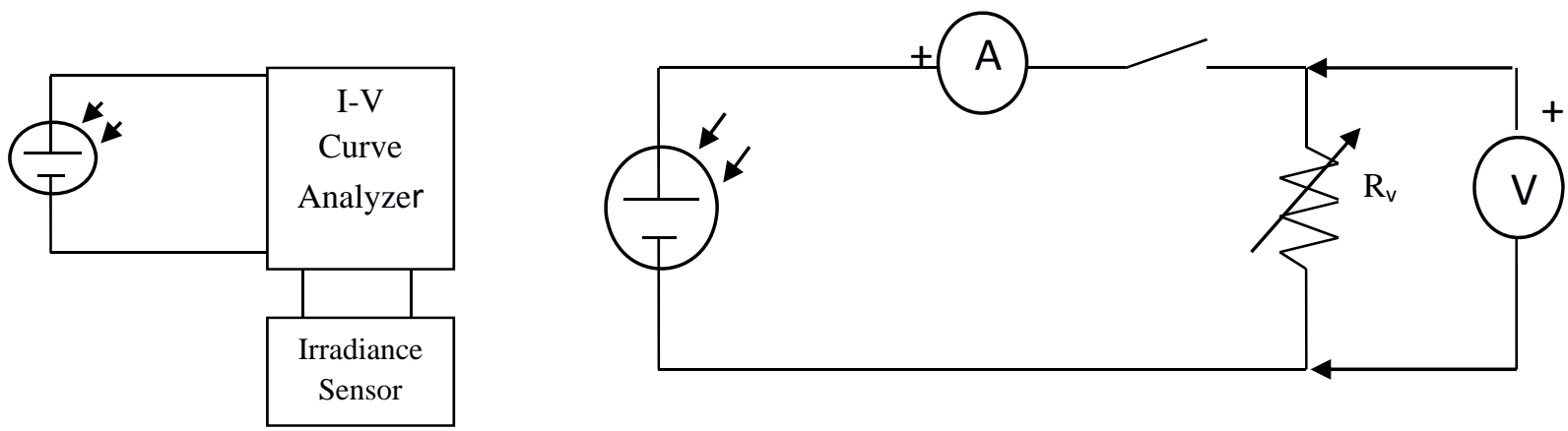

Figure 2. PV circuits for outside (left) and inside (right) setups used in laboratory experiments 2 and 6

One of the more advanced laboratory modules presented in Table 3 is Experiment 8 with inverters. This experiment must be completed inside due to additional electronic equipment utilized in the lab, such as oscilloscope and wattmeter. The functional block diagram for Experiment 8 is given in Figure 3.

\begin{tabular}{l}
\hline Experiment 8: Inverters \\
\begin{tabular}{|l|}
\hline PART A \\
Waveforms, Frequency Spectrum and Load Response: Oscilloscope is used to \\
measure the changes in the maximum voltage, duty cycle and waveform shape \\
produced by various inverters (pure sine, pulse-width modulated, and modified \\
square-wave) in response to load adjustments.
\end{tabular} \\
\hline $\begin{array}{l}\text { PART B } \\
\text { Efficiency of the Inverter: Efficiency of several inverters (pure sine, modified square } \\
\text { wave, and pulse-width modulated) is determined for various loads by taking power } \\
\text { measurements on the DC and AC sides of the inverter. }\end{array}$ \\
\hline Analysis of results and questions. \\
\hline
\end{tabular}

Figure 3. Functional diagram for Experiment 8 
In part $\mathrm{A}$ of the inverter lab, students wire the circuit presented in Figure 4 for pure sine, pulsewidth modulated (PWM) and modified square-wave inverters. They use oscilloscope to measure maximum voltage, period, duty cycle, and shape of the resulting waveforms under no load and under various load conditions. In part B, students wire circuit presented in Figure 5 with DC power supply instead of solar module and take power measurements on the DC and AC side of the inverter to calculate inverter efficiency. This part is performed for no load and for various load conditions as well.

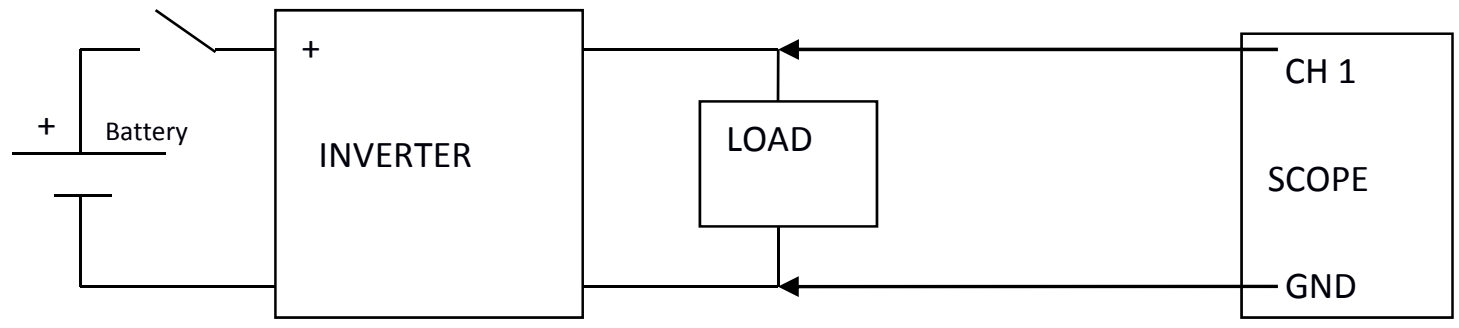

Figure 4. Circuit diagram for Part A of Experiment 8

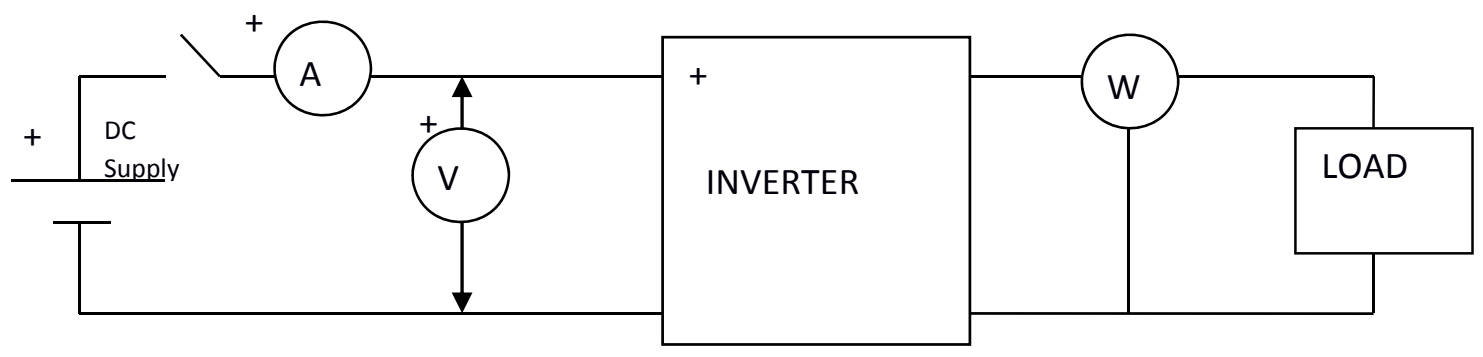

Figure 5. Circuit diagram for Part B of Experiment 8

After running the lab sequence for the first semester during the spring of 2011, we added more equipment that is used by the photovoltaic industry and which we were not aware of at the time the lab was created. For example, we added I-V Curve Analyzers for small panels from IMT Solar ${ }^{9}$ to be able to measure panel's I-V curve profile automatically instead of doing it manually with rheostat and digital multimeters. This stream-lined the lab experiments with series/parallel panel configurations and shading analysis. It also introduced students to the up-to-date testing technology that is used in the field. However, this testing equipment might not be a priority for someone who is building the lab on the low budget as it costs over $\$ 3,500$ per setup. The funding for the I-V Curve Analyzers was also obtained from Carl D. Perkins Career and Technical Education Act grant. In addition, it is important to mention that the I-V Curve Analyzer can only be used in the outside lab setups with $5 \mathrm{~W}$ panels. Figure 6 shows the I-V curves obtained with the I-V Curve Analyzer for the $5 \mathrm{~W}$ polycrystalline silicon panel under direct sunlight (left) and under the MH/HPS source (right). Figure 6 indicates substantial deterioration of the panel's output when exposed to artificial light source relative to the natural sunlight resulting in faulty software performance based on such data. The most plausible reason for such deterioration is the fact that panel is producing the current below the normal current range for the I-V Curve Analyzer due to the excessive heating of the panel and non-uniform 
irradiance of the panel's surface from the artificial light source. Panels, larger than $5 \mathrm{~W}$, that are necessary to increase the current intensity, would not work due to the small physical size of the light source. Panels, smaller than 5W, can be irradiated uniformly by the MH/HSP source but would produce even smaller current.
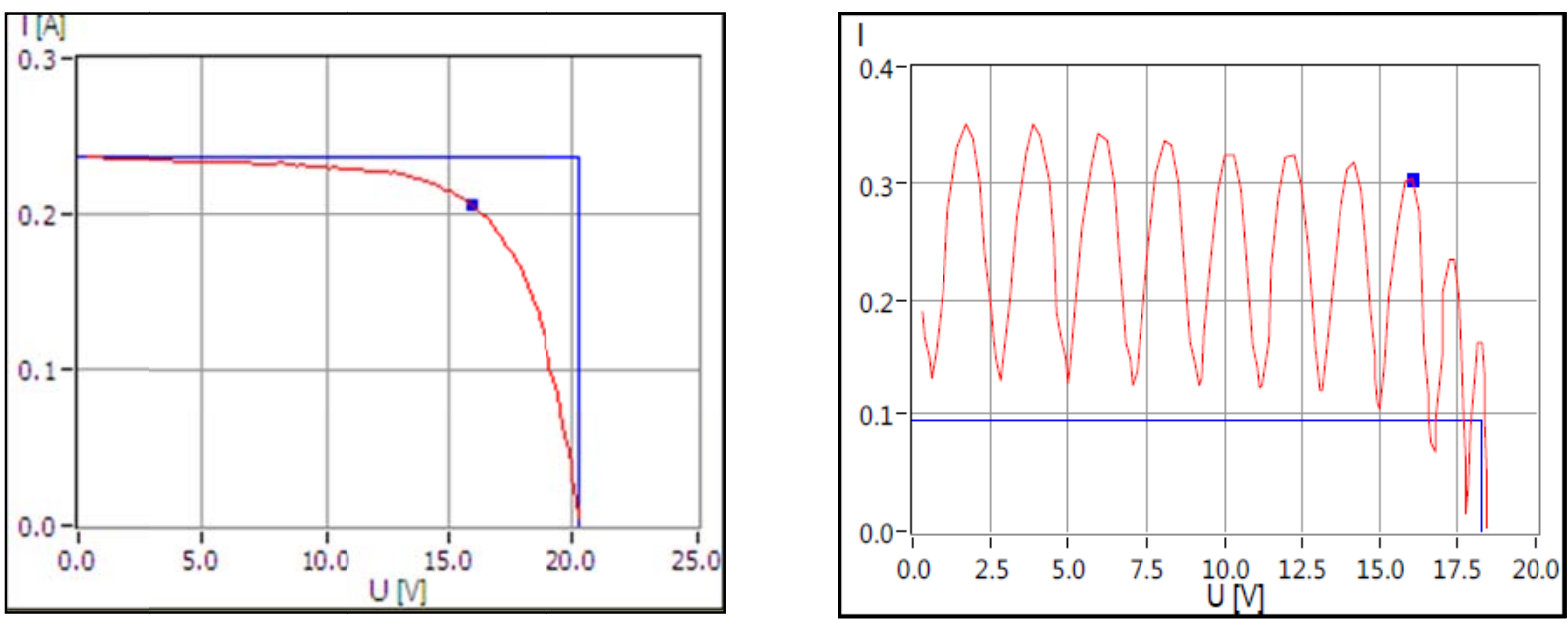

\section{Figure 6. I-V curves for $5 \mathrm{~W}$ panel under direct sunlight (left) and under MH/HPS source (right)}

Another piece of equipment we were able to add was a Marlec 60 Watt wind turbine with the hybrid charge controller. The turbine is mounted on a four foot tall stand and placed a few feet away from a high speed industrial fan. The hybrid charge controller can accept up to a 100W PV panel. This allows our students to get familiar with the process of installing, running and disengaging of the hybrid PV/wind system. We also had to add more dedicated digital multimeters since some of the experiments required 2 or 3 meters to obtain all the necessary measurements.

\section{Assessment}

Overall, course and corresponding laboratory were run twice, during spring and fall semesters in 2011. Students' progress in the lecture course was assessed with the combination of in-class tests, homework, hands-on homework assignments and group design project. The progress in the laboratory course was assessed based on the lab performance (including lab safety), laboratory reports, and individual research project. The research project required students to identify and discuss existing or proposed PV projects and their impact on the society. The inclusion of such project in the course mixture targeted the development of life-long learning skills in the technical field. The assessment from spring semester indicated the presence of some weaknesses. For instance, the successful completion of the research project requires development and application of the research skills such as: information searching techniques and strategies; evaluation of the information quality and credibility; proper source citation; identification of proper information sources such as databases, peer-reviewed journals, and credible webpages. Unfortunately, in most of the two-year technology programs at the community colleges, students do not have proper exposure to the information literacy tools that would allow them to conduct thorough research of their topic. To overcome this shortcoming, we incorporated two hours of information 
literacy instruction into the course during following fall of 2011 semester. The college's library department conducted actual training earlier in the semester. As a result, the quality of students' research projects increased on average by $4 \%$. Furthermore, addition of industry-specific equipment mentioned above (I-V curve analyzers, extra digital multi-meters, wind turbines for hybrid systems) helped to increase students’ lab performance on average by $3 \%$.

Students' evaluations were conducted at the end of each course and provided the detailed feedback on the following: overall course format; individual components of the course such as design project; level of hands-on experience; comparison of expected and actual learning quality; development of life-long learning skills. On the scale of 1 (poor) to 5 (excellent), the average score was 4.63 indicating high level of students' satisfaction from the courses.

\section{Conclusion}

The lecture and lab courses in Photovoltaic Systems proved to be a success. They provided students with fairly deep theoretical and practical knowledge of PV systems. Students gained hands-on experience in working with PV systems and system components. They also gained experience in sizing and designing the real-life PV systems. Based on the success of the PV courses, we are currently working on expanding department's offerings in the renewable energies to the new wind power course.

\section{References}

1. Santosh Kurinec and Michael A. Jackson, A New Course on Photovoltaics for Engineering and Science Curricula, ASEE St. Lawrence Chapter, March 2010, http://stl.asee.org/papers_2010/jacksonpv.pdf.

2. Hudson Valley Community College, Photovoltaic Installation Certificate. Retrieved from https://www.hvcc.edu/catalog/programs/eit/pvc.html.

3. Solar Energy International, Solar Training - Electric. Retrieved from http://www.solarenergy.org/solar-training-electric.

4. Consortium for Education in Renewable Energy Technologies (CERET). The CERET Train the Trainers Academies. Retrieved from http://www.ceret.us/trainer/.

5. Paul Lynn, Electricity from Sunlight - An Introduction to Photovoltaics, John Wiley \& Sons Ltd, 2010.

6. Solar Energy International, Photovoltaics: Design and Installation Manual, SEI, 2007.

7. James Dunlop, Photovoltaic Systems, $2^{\text {nd }}$ edition, NJATC, July 2009.

8. Roger Messenger and Jerry Ventre, Photovoltaic Systems Engineering, $3^{\text {rd }}$ edition, CRC Press, February 2010.

9. IMT Solar, Handheld PV I-V Curve Analyzer:Mini-KLA. Retrieved from: http://imtsolar.com/page/Handheld-PV-I-V-Curve-Analyzer/57.html 